\title{
Improving Speaking Skill of the Tenth Grade Students through Mingle Model
}

\author{
Indrawati ${ }^{1}$, Rofi Inayaturrohmah ${ }^{2}$ \\ ${ }^{1}$ State Islamic Institute of Syaikh Abdurrahman Siddik Bangka Belitung \\ ${ }^{2}$ State Islamic Institute of Syaikh Abdurrahman Siddik Bangka Belitung
}

indrawati.fr@gmail.com

Received: 01-11-2020 /Accepted: 25-12-2020 / Doi: https://doi.org/10.32923/sci.v5i1.1448

\begin{abstract}
The purposes of this study are to unveil the application of Mingle Model to enhance students' speaking skill at tenth grade of Vocational High School Number 1 Simpangkatis, Bangka and to clarify whether there was or not a significance difference in student mastery of speaking skills between two classes; experimental class where Mingle Model was implemented and non-experimental class where there was no new model given by teacher. Observation and test were the techniques used in collecting the data. This study used quantitative approach with quasi experimental design. There were 72 students from two classes taken as the sample purposively; TKI 1 and TKI 2. This research applied Mingle Model as the treatment given to the experimental class. This study considers some aspects in speaking; comprehension, pronunciation, vocabulary, grammar, and fluency. From the finding, it showed that the students who were given Mingle Model treatment reached better or higher score in the post test than the students who were taught by Non-Mingle Model. In this case, the alternative hypothesis (Ha) was accepted as t-obtained, 3.56, was higher than the critical value of t-table, 2.00. Based on the evidence above, the research concluded that between the experimental and control group there was a considerable difference of students' speaking performances. Therefore, the findings of this study confirmed that Mingle Model was effective to increase the students' speaking ability.
\end{abstract}

Keywords: mingle model, speaking ability, speaking achievement, speaking performance, speaking skill. 


\section{Introduction}

Elena Borzova stated that mingle is an activity where a student approaches a classmate, talks for a while, and then moves on to speak to another classmate(Borzova, 2014). According to Borzova, mingle model is a strategy in teaching speaking where the students move around the class, each student must take part in this activity. A student might try to speak to one of their classmates about the topic given by the teacher. This can be done either in pairs or in small group. They have chance to speak, listen, discuss, and take notes. This kind of talk should be done in form of face to face communication. After one student finished the small talk with his friend, he should change his partner. It can be done randomly or the teacher can set the rule for the movement in the class (sitting, standing, moving clock wise or counter clock wise).

Before conducting this research, the writers did a preliminary study in Vocational School No. 1 Pangkalpinang. The writer did a proficiency test for the students of eight graders. From that kind of test, the writers noticed that one of skill which was needed to be improved was speaking skill. From the speaking test, it was found out the students' comprehension, vocabulary, grammar, fluency, and accuracy were not good enough. This barrier made them difficult to communicate English with others orally whereas oral communication is very important in conveying messages with others. Also, they found it difficult to deliver their ideas in speaking because they had less vocabulary and less comprehension of grammar(Dewi, Kultsum, \& Armadi, 2016; Ganna, 2018; Indrawati \& Widiana, 2019). All above factors were the indicators of low speaking ability of the students at Vocational High School Number 1 Simpangkatis. Noticing those phenomena which were usually found in speaking, the researcher intended to seek a perfect strategy to improve the students' speaking skill at Vocational High School Number 1 Simpangkatis by giving treatment of Mingle Model implementation in students; learning activites.

Borzova argues that Mingle Model is a kind of classroom regulation or guidance technique which let the learners to be active to go around the class, give the students chance to talk and listen freely(Borzova, 2014). It can create a very enjoyable, comfortable learning atmosphere that can enrich the level of ability to communicate well in English (communicative competence). By implementing Mingle model, the teacher can avoid monotony of the lesson in the class and provide some practice for every student (Borzova, 2014). Mingle has two general parts, act mingle itself and do presentation (Darmayenti \& Nofiadri, 2015). Mingle model was introduced and piloted by Pollard and Hess. It can be adapted into a new approach, strategy or technique for teaching speaking skill (Darmayenti \& Nofiadri, 2015).

Here is the implementation of Mingle model as a treatment in Experimental class, the steps of were proposed by Darmayanti dan Novel Nofriadi. The teacher writes some expressions or notes in the cards and then he asks the students to pronounce the expressions correctly. After that, the students are given the cards, and the teacher manages times for this mingles activity which the students do in pairs or small groups. In these groups they have to actively talk, listen, and participate in English and approach their friends while completing the list of questions in the card in every different partner. Teacher becomes facilitator and observer in this activity. He should carefully examine and observe the students' activeness and participation. After finishing those activities, the teacher facilitates the students to report their works in front of the class. And the end of students' presentation, the teacher reviews and evaluates their work.

The researcher limited this study by only focusing on enhancing the students' speaking ability. The intention was to develop students' skill in speaking through Mingle Model. The type of speaking performance in this research was personal recount. The researcher focused on five aspects on assessing speaking, those were: pronunciation, grammar, fluency, comprehension and vocabulary. The topics were My holiday, My good experience and My bad experience.

Considering the limitation of this experimental study, research problems could be planned into two parts:

1. How was the implementation of Mingle Model in speaking ability of ten graders of Vocational High School Number 1 Simpangkatis in Academic Year 2018?

2. Was there any significant difference in speaking skill between the students who were given Mingle 
Model as a treatment and the students who were taught by using conventional method?

\section{Method of Research}

The method of this study was quantitative approach. As the purpose of this study was to investigate whether Mingle Model could significantly develop the students' skill of speaking, the experimental research was proposed (Rasinger, 2013). Therefore, this study used the quasi-experimental design as one of type experimental research in quantitative approach Fraenkel \& Wallen, 2009).The basic characteristic of this quasi experimental research is the dependent variable are put in groups; experimental group which will be given treatment and control group which will be given no treatment, no new model or technique during the research ((0. Creswell, 2012).

\subsection{Data type and source}

The population of this study was all of the students of the first graders of Vocational School No. 1 Simpangkatis, Bangka Tengah in academic year of 2017/2018.

Table 1.Population of Study

\begin{tabular}{l|l|c}
\hline No & Class & Number of Student \\
\hline $\mathbf{1}$ & X TKI 1 & 36 \\
\hline $\mathbf{2}$ & X TKI 2 & 36 \\
\hline $\mathbf{3}$ & X TKI3 & 36 \\
\hline $\mathbf{4}$ & X Otomotif 1 & 36 \\
\hline $\mathbf{5}$ & X Otomotif 2 & 36 \\
\hline $\mathbf{6}$ & X Otomotif 3 & 35 \\
\hline $\mathbf{7}$ & Otomotif 4 & 35 \\
\hline $\mathbf{8}$ & TITL & 36 \\
\hline \multicolumn{2}{l}{ Number of Population } & $\mathbf{2 6 9}$ \\
\hline
\end{tabular}

Resources: SMKN 1 Simpangkatis (2017/2018)

The researcher considered two classes of the tenth grade as the samples of this research. In this study, the English teacher of Vocational High School Number 1 Simpangkatis who taught classes of the ten grade suggested to take X TKI 1 and X TKI 2 as the samples. She recommended those classes because she thought that they had low speaking ability but had bigger potential than others to get a good result in speaking development. It would be very useful for students and school. Then, according to the school teacher, students' speaking ability in X TKI 2was lower than X TKI 1. Because of that statement, the researcher decided X TKI 1 as control and X TKI 2 as experimental group.It means that, the lower group should get treatment to improve their speaking achievement. Experimental group would be given a treatment by using mingling model to improve their speaking skill. The sample is figured out in the table below.

Table 2. Sample of study

\begin{tabular}{c|c|c|c|c}
\hline No & Class & Male & Female & Number of Student \\
\hline 1 & $\begin{array}{c}\text { X TKI 1 } \\
\text { Control Group }\end{array}$ & 7 & 29 & 36 \\
\hline 2 & $\begin{array}{c}\text { X TKI 2 } \\
\text { Experimental Group }\end{array}$ & 10 & 26 & 36 \\
\hline
\end{tabular}




\section{Technique for Collecting Data}

To answers the research problems (problems of study), the instruments are needed. For research problem number one related to the implementation of Mingle Model, observation is needed and to answer research problem number two, tests are acquired to be given tho samples of the study.

a. Observation

The observation is needed to see students' reaction toward the treatment given during the study. According to Fraenkel, observation should be conducted for two reasons; the first is in order to see the object of the research, in this case is the students, respond to the technique and the measurements of all students activities during the observation (Wallen \& Fraenkel, 2001). During the observation, teacher can use observation sheet to measure the students' activeness, participation, presence, attention, dealing with questions and answers and many others. The observation sheet should be filled by the researchers every meeting during the research either for experimental or control group.

b. Test

The second instrument used in this study was pre-test and post test of speaking ability. This test was used to measure the students mastery of speaking ability; comprehension, vocabulary, pronunciation, fluency, and accuracy(Marczyk, DeMatteo, \& Festinger, 2005). The pre-test was given before treatment, and post test was given after treatment. The main score of these kinds of test would be analyzed using statistical analysis, T-test. The purpose of using T-test is to see whether there was a significant different for students' speaking performances before and after treatment, and the differences of the mean scores of speaking ability between those two groups, experimental and control group.

\section{Result}

\section{The Result of Observation}

In this part, the researcher would like to discuss the result of the observation both experimental and control group.

\section{a. The Result of Observation in Experimental Group}

These were the result of observation in experimental group. It showed the students' attendance, attention, activeness, and doing all activities.

Table 3. The Result of Observation

\begin{tabular}{|c|c|c|c|c|c|c|c|c|c|c|c|c|}
\hline \multirow[b]{2}{*}{ 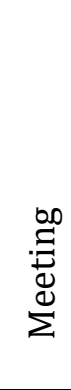 } & \multicolumn{3}{|c|}{ 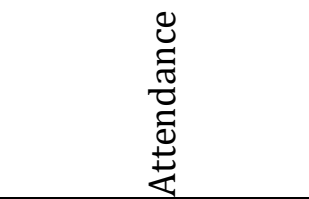 } & \multicolumn{3}{|c|}{ 号 } & \multicolumn{3}{|c|}{$\begin{array}{l}\text { Activeness in } \\
\text { Asking and } \\
\text { Answering } \\
\text { Question }\end{array}$} & \multicolumn{3}{|c|}{$\begin{array}{l}\text { Doing All The } \\
\text { Activities }\end{array}$} \\
\hline & 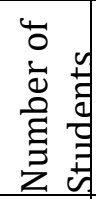 & 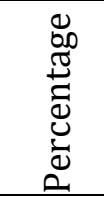 & $\begin{array}{l}\overrightarrow{0} \\
0 \\
0 \\
0 \\
0 \\
0\end{array}$ & 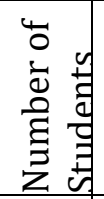 & 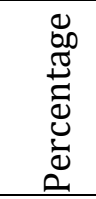 & 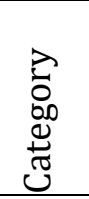 & 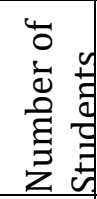 & 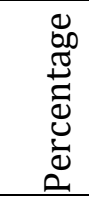 & $\begin{array}{l}\lambda \\
0 \\
0 \\
0 \\
0 \\
0 \\
0\end{array}$ & 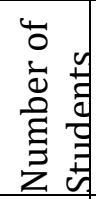 & 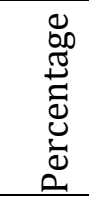 & $\begin{array}{l}\lambda \\
0 \\
0 \\
0 \\
0 \\
0\end{array}$ \\
\hline 1 & $\begin{array}{l}\text { Pre } \\
\text { Tes } \\
t\end{array}$ & $\begin{array}{l}\text { Pre } \\
\text { Test }\end{array}$ & $\begin{array}{l}\text { Pre } \\
\text { Test }\end{array}$ & $\begin{array}{l}\text { Pre } \\
\text { Tes } \\
t\end{array}$ & $\begin{array}{l}\text { Pre } \\
\text { Test }\end{array}$ & $\begin{array}{l}\text { Pre } \\
\text { Test }\end{array}$ & $\begin{array}{l}\text { Pre } \\
\text { Tes } \\
\mathrm{t}\end{array}$ & $\begin{array}{l}\text { Pre } \\
\text { Test }\end{array}$ & $\begin{array}{l}\text { Pre } \\
\text { Test }\end{array}$ & $\begin{array}{l}\text { Pre } \\
\text { Tes } \\
\mathrm{t}\end{array}$ & $\begin{array}{l}\text { Pre } \\
\text { Test }\end{array}$ & $\begin{array}{l}\text { Pre } \\
\text { Test }\end{array}$ \\
\hline
\end{tabular}


Scientia: Jurnal Hasil Penelitian Vol. 5, Nomor 2, Desember 2020

https://jurnal.lp2msasbabel.ac.id/index.php/sci

\begin{tabular}{|c|c|c|c|c|c|c|c|c|c|c|c|c|}
\hline 2 & 34 & $94 \%$ & $\begin{array}{l}\text { Very } \\
\text { Good }\end{array}$ & 33 & $91 \%$ & $\begin{array}{l}\text { Very } \\
\text { Good }\end{array}$ & 28 & $77 \%$ & Good & 31 & $86 \%$ & $\begin{array}{l}\text { Very } \\
\text { Good }\end{array}$ \\
\hline 3 & 34 & $94 \%$ & $\begin{array}{l}\text { Very } \\
\text { Good }\end{array}$ & 24 & $66 \%$ & $\begin{array}{l}\text { Aver } \\
\text { age }\end{array}$ & 27 & $75 \%$ & Good & 34 & $88 \%$ & $\begin{array}{l}\text { Very } \\
\text { Good }\end{array}$ \\
\hline 4 & 32 & $88 \%$ & $\begin{array}{l}\text { Very } \\
\text { Good }\end{array}$ & 32 & $88 \%$ & $\begin{array}{l}\text { Very } \\
\text { Good }\end{array}$ & 30 & $83 \%$ & Good & 33 & $83 \%$ & Good \\
\hline 5 & 34 & $94 \%$ & $\begin{array}{l}\text { Very } \\
\text { Good }\end{array}$ & 34 & $94 \%$ & $\begin{array}{l}\text { Very } \\
\text { Good }\end{array}$ & 28 & $77 \%$ & Good & 32 & $88 \%$ & $\begin{array}{l}\text { Very } \\
\text { Good }\end{array}$ \\
\hline 6 & 34 & $94 \%$ & $\begin{array}{l}\text { Very } \\
\text { Good }\end{array}$ & 34 & $94 \%$ & $\begin{array}{l}\text { Very } \\
\text { Good }\end{array}$ & 30 & $83 \%$ & Good & 35 & $91 \%$ & $\begin{array}{l}\text { Very } \\
\text { Good }\end{array}$ \\
\hline 7 & 35 & $97 \%$ & $\begin{array}{l}\text { Very } \\
\text { Good }\end{array}$ & 35 & $97 \%$ & $\begin{array}{l}\text { Very } \\
\text { Good }\end{array}$ & 24 & $66 \%$ & Good & 32 & $86 \%$ & $\begin{array}{l}\text { Very } \\
\text { Good }\end{array}$ \\
\hline 8 & 36 & $\begin{array}{l}100 \\
\%\end{array}$ & $\begin{array}{l}\text { Very } \\
\text { Good }\end{array}$ & 32 & $88 \%$ & $\begin{array}{l}\text { Very } \\
\text { Good }\end{array}$ & 29 & $80 \%$ & Good & 34 & $91 \%$ & $\begin{array}{l}\text { Very } \\
\text { Good }\end{array}$ \\
\hline 9 & 36 & $\begin{array}{l}100 \\
\%\end{array}$ & $\begin{array}{l}\text { Very } \\
\text { Good }\end{array}$ & 34 & $94 \%$ & $\begin{array}{l}\text { Very } \\
\text { Good }\end{array}$ & 30 & $83 \%$ & Good & 32 & $75 \%$ & Good \\
\hline 10 & 36 & $\begin{array}{l}100 \\
\%\end{array}$ & $\begin{array}{l}\text { Very } \\
\text { Good }\end{array}$ & 29 & $80 \%$ & Good & 33 & $63 \%$ & $\begin{array}{l}\text { Aver } \\
\text { age }\end{array}$ & 32 & $91 \%$ & $\begin{array}{l}\text { Very } \\
\text { Good }\end{array}$ \\
\hline 11 & 36 & $\begin{array}{l}100 \\
\%\end{array}$ & $\begin{array}{l}\text { Very } \\
\text { Good }\end{array}$ & 30 & $83 \%$ & Good & 27 & $75 \%$ & Good & 34 & $86 \%$ & $\begin{array}{l}\text { Very } \\
\text { Good }\end{array}$ \\
\hline 12 & $\begin{array}{l}\text { Pos } \\
t \\
\text { Tes } \\
t\end{array}$ & $\begin{array}{l}\text { Post } \\
\text { Test }\end{array}$ & $\begin{array}{l}\text { Post } \\
\text { Test }\end{array}$ & $\begin{array}{l}\text { Pos } \\
\mathrm{t} \\
\text { Tes } \\
\mathrm{t}\end{array}$ & $\begin{array}{l}\text { Post } \\
\text { Test }\end{array}$ & $\begin{array}{l}\text { Post } \\
\text { Test }\end{array}$ & $\begin{array}{l}\text { Pos } \\
\mathrm{t} \\
\text { Tes } \\
\mathrm{t}\end{array}$ & $\begin{array}{l}\text { Post } \\
\text { Test }\end{array}$ & $\begin{array}{l}\text { Post } \\
\text { Test }\end{array}$ & $\begin{array}{l}\text { Pos } \\
\mathrm{t} \\
\text { Tes } \\
\mathrm{t}\end{array}$ & $\begin{array}{l}\text { Post } \\
\text { Test }\end{array}$ & $\begin{array}{l}\text { Post } \\
\text { Test }\end{array}$ \\
\hline
\end{tabular}

Based on the result of the table above could be read as a scale of value in this following table:

Table 4. The Scale of Value

\begin{tabular}{l|l}
\hline Scale & Category \\
\hline $85-100 \%$ & Very Good \\
\hline $69-84 \%$ & Good \\
\hline $53-68 \%$ & Average \\
\hline$<53 \%$ & Low \\
\hline
\end{tabular}

The table above showed the observation result of experimental group during twelve meetings. There were four aspects. Those were attendance, attention, activeness in asking and answering question and doing all the activities. The result of students' attendance, the pre test and post test was done by all 36 students. Also, the eighth, ninth, tenth and eleventh meetings were attended by all students, $100 \%$ was 36 students. But in the other meeting, there were some students not attending the class. It was around one up to four. Over all, it was still in very good category.

The second aspect was students' attention. The students' attention was very unpredictable. The second, fourth up to eighth were in very good category. It was around $88 \%-97 \%$. It showed that most of students showed their attention to the lesson. In the tenth and el eventh meeting was in good category. It was $80 \%$ and $83 \%$. But in the third meeting, it was the lowest attention of the students. It was average category, $66 \%$. 
Next is students' activeness aspect. It showed $77 \%$ in the second meeting, $75 \%$ in the second meeting, $83 \%$ in the third meeting, $77 \%$ in the forth meeting, $83 \%$ in the fifth meeting, $66 \%$ in the sixth meeting, $80 \%$ in the seventh meeting, $83 \%$ in the eighth meeting, $63 \%$ in the ninth meeting and $75 \%$ in the tenth meeting. The sixth and the ninth were average category. The others were in good category.

The last was doing all activities aspect. Based on the observation result there was no meeting have low category. There were eight meetings had good category and others had good category. It showed that almost of students wanted to do all activities was required. The class reached good and very good category which $75 \%$ $91 \%$ of students were active enough for doing all activities.

\section{b. The results of pre-test and post-test in experimental group}

In order to see the students' speaking skill after being taught by Mingle Model in experimental group which was X TKI 2, the researcher conducted pre-test and post test. Every student retold their stories about $M y$ Holiday, My Bad Experience and My Good Experience. The scores were given by raters after listening to the students' recording about those topics above. The experimental group scores of pretest and post-test and the score category were presented in appendix.

Table 5. The Percentage Score of Experimental Group

\begin{tabular}{l|l|l}
\hline \multicolumn{2}{l}{ Pretest Result } \\
\hline Number of Students & Percentage & Grade \\
\hline- & - & Good to excellent \\
\hline 6 & $17 \%$ & Average to good \\
\hline 7 & $19 \%$ & Poor to average \\
\hline 23 & $64 \%$ & Poor \\
\hline Post-Test Result & \multicolumn{2}{|l}{} \\
\hline Number of Students & Percentage & Grade \\
\hline 1 & $3 \%$ & Good to excellent \\
\hline 31 & $86 \%$ & Average to good \\
\hline 4 & $11 \%$ & Poor to average \\
\hline- & - & Poor \\
\hline
\end{tabular}

\section{c. Statistic analysis of pre-test and post-test in experimental group}

This was the result of paired sample statistics in experimental group:

Table 6. Paired Samples Statistics

\section{Paired Samples Statistics}

\begin{tabular}{l|l|l|l|l|l}
\hline \multicolumn{2}{l|}{} & Mean & N & Std. Deviation & Std. Error Mean \\
\hline \multirow{3}{*}{ Pair 1 } & PRE TEST & 44.0556 & 36 & 9.94253 & 1.65709 \\
\cline { 2 - 6 } & POST TEST & 69.2222 & 36 & 7.29035 & 1.21506 \\
\hline
\end{tabular}


https://jurnal.lp2msasbabel.ac.id/index.php/sci

Table 6 provides the mean scores of pre-test an post-tests of students from experimental group. The mean of pre-test score was 44.0556, while post-test score was 69.222, much higher than the scores before the treatment was given.

Table 7.Paired Samples Test

Paired Samples Test

\begin{tabular}{|c|c|c|c|c|c|c|c|c|}
\hline & \multicolumn{5}{|c|}{ Paired Differences } & \multirow{3}{*}{ 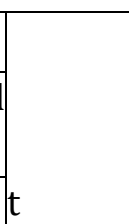 } & \multirow[b]{3}{*}{$\mathrm{df}$} & \multirow{3}{*}{$\begin{array}{l}\text { Sig. } \\
\text { tailed) }\end{array}$} \\
\hline & \multirow[b]{2}{*}{ Mean } & \multirow{2}{*}{$\begin{array}{l}\text { Std. } \\
\text { Deviation }\end{array}$} & \multirow{2}{*}{$\begin{array}{l}\text { Std. Error } \\
\text { Mean }\end{array}$} & \multicolumn{2}{|c|}{$\begin{array}{l}95 \% \text { Confidence Interval } \\
\text { of the Difference }\end{array}$} & & & \\
\hline & & & & Lower & Upper & & & \\
\hline \begin{tabular}{r|lr} 
Pair 1 PRE & TEST \\
& POST TEST
\end{tabular} & -25.166 & 6.9343 & 1.1557 & -27.512 & -22.820 & -21.77 & 35 & .000 \\
\hline
\end{tabular}

For paired sample test result, the paired differences was showed above that the mean between pre-test and pots-test in the experimental group was 25.16, standard deviation was 6.93, standard error mean was 1.15 and t-obtained was 21.77 , at the significant .000 for two tailed and degree of freedom 35 . Based on those result above the $\operatorname{sig}(2$ tailed) .000 was lower than the value of probability .05. It meant that there was a significant difference for students' speaking skill after being taught by using Mingle Model in experimental group.

\section{d. The statistics analysis of students' post-test between control and experimental group}

This part would discuss about the statistic of the students' post test between control and experimental.

Table 8. Independent Samples Test

\begin{tabular}{|c|c|c|c|c|c|c|c|c|c|c|}
\hline \multicolumn{11}{|c|}{ Independent Samples Test } \\
\hline & & $\begin{array}{r}\text { Leven } \\
\text { for Equ } \\
\text { Vari }\end{array}$ & $\begin{array}{l}\text { S Test } \\
\text { lity of } \\
\text { ces }\end{array}$ & \multicolumn{7}{|c|}{ t-test for Equality of Means } \\
\hline & & \multirow[b]{2}{*}{$\mathrm{F}$} & \multirow[b]{2}{*}{ Sig. } & \multirow[b]{2}{*}{$\mathrm{T}$} & \multirow[b]{2}{*}{ Df } & \multirow{2}{*}{$\begin{array}{c}\text { Sig. } \\
(2- \\
\text { tailed } \\
]\end{array}$} & \multirow{2}{*}{$\begin{array}{c}\text { Mean } \\
\text { Difference }\end{array}$} & \multirow{2}{*}{$\begin{array}{l}\text { Std. Error } \\
\text { Difference }\end{array}$} & \multicolumn{2}{|c|}{$\begin{array}{l}95 \% \text { Confidence } \\
\text { Interval of the } \\
\text { Difference }\end{array}$} \\
\hline & & & & & & & & & Lower & Upper \\
\hline \multirow{2}{*}{$\begin{array}{l}\text { THE SORE } \\
\text { OF } \\
\text { SPEAKIN } \\
\text { G SKILL }\end{array}$} & \begin{tabular}{|l} 
Equal \\
variances \\
assumed \\
\end{tabular} & 3.37 & .071 & 3.56 & 69 & .001 & 5.62222 & 1.57787 & 2.474 & 8.769 \\
\hline & \begin{tabular}{|l} 
Equal \\
variances \\
not \\
assumed
\end{tabular} & & & 3.57 & 66.8 & .001 & 5.62222 & 1.57322 & 2.481 & 8.762 \\
\hline
\end{tabular}

Tabel 9 showed us the statistical analyses of independent sample test where it compares between the post-test from two classes. It was obviously seen that t-obtained was higher than t-table, meaning that the Mingle Model was successfully implemented. And as a result, the students' speaking ability developed significantly. 


\section{Discussion}

In this part, the researcher would like to discuss the interpretation of the implementation and observation, and the interpretation of statistical analyses.

1. The Interpretation of Implementation and Observation

In this part, the researcher would like to describe in detail some of the interpretations of the research result. In the experimental group showed an improvement during twelve meetings which had been finished. This class consisted of 36 students who had been cooperative did everything needed together with the researcher. The researcher had explained that the researcher taught the class by using Mingle Model in order to improve student's speaking skill. Almost in every meeting, the student practiced their speaking through going around the class and completed the difference list of question in meeting. The main topics were about holiday, bad experience and good experience.

For mingle model, the steps were very easy to do by students. This model gave every student a chance for practice their speaking in every meeting. They had chance for asking and answering each question with their partner. In the first meeting, they did not seemed interesting in it. But, after the researcher explained clearly and showed them the example how to do it, they really wanted to try. In that meeting, they asked the teacher a lot of question about how to say some words in English, when they wanted to answer their friend question. In every meeting, they improved little by little. They brought dictionary in every meeting to find the word they did not know, in order to answer their friend's question faster. The class was noisy because of their laugh and their speaking but they could enjoy the class. They used three topics above. They had less confident when speaking in English.

By this model, they could practice their speaking from the nearest people in the class. Then some students came forward to present their story. That time, the researcher did little bit of error as knowledge for the students about the aspect of speaking. It could be the pronunciation, grammar, fluency, comprehension or vocabulary. The result showed that they could speak better than before and the grammar was improved after having Mingle Model during learning process.

Based on the observation sheet, the percentage of students in every meeting was unpredictable. The students were practiced to participate in every meeting. They were trained to be brave to talk during research. They had to speak in the chance given. The presence of students was in very good category during meetings, both of classes, control and experimental group. One of meeting had average category in attendance. It was in the ninth meeting of control class. For the attention part, there was very good, good and average category both control and experimental. For students' activeness were good in the eight meetings and average category in two meetings for experimental group. Then, in the control group, there were four in low category, there were one in very good category and five meetings in good category.

The students of experimental group were active enough for asking their partner. But there were some meeting got average category. It was the seventh and tenth meeting. Others had good category in their activeness. They felt afraid to make mistake. They were not confident saying any word in English. So that, the teacher taught them some expressions before practicing mingle model. Then they practiced mingle model by trying to use English it in the conversation. Everyone was trying in every meeting. For doing all activity, all students were able enough to do the activities during meetings. The ninth meeting in control group was the lowest. It was average category.

\section{The Interpretation of Statistical Analysis}

The statistical analysis provides data through mathematical process and the output might be in the forms of numbers, tables, graphs, and figures (Kothari, 2004). The experiments of both classes were conducted 12 (twelve) times. Pre-test was given in the first meeting and post-test was done at last meeting. To see the differences of the students' pre-test and post-test scores, statistical analyses, T-test was used. To see the differences between pre-test and post-test of the two classes, Independent T-test was implemented, while to 
measure the post-test between the two groups, Paired Sample T-test was used. The mean score of the pre-test in the experimental group was 44.0566 and the post test was 69.222, much higher than the pre-test score before the treatment of Mingle Model was given. And when the post-test of control group and experimental group was analyzed using T-Test of statistical analysis, it was obviously seen that the t-obtained (3.56) was higher than the critical value of t-table a(2.00). It can be inferred that there was a significant difference between the two classes, one which Mingle Model was implemented and other which was taught by using conventional method.

There were some studies who confirmed that Mingle Model was effective in developing students' mastery of speaking skill, among of them were study conducted by Elena Borzova (Borzova, 2014) and research implemented by (Darmayenti \& Nofiadri, 2015), Borzova argues that Mingle Models covers three important tasks; language (form-focused function), communicative function, and meaningful mingle. Language means the teacher tries to enhance and increase the student's skills, specifically for grammar and vocabulary related to topic learnt by the students. The second stage is communication function where the students practice what they have got in the form-focused function.

Given a simple situations, the students tried to achieve the communicative function in using expressions, grammar and vocabularies they know. Those three stages proposed by Borzova in implementing Mingle Model are in line with some statements, opinions and theories related to communicative competence and performance proposed by Gunn, Pakula and Jack Richards (Gunn, 2003; Pakula, 2019; Richards, 2001). Furthermore, Borzova claimed that Mingle Mode is a very challenging strategy in developing the students' speaking skills because it can create a convenient learning atmosphere where it can increase the quality of communicative competence and performance of the students' speaking ability. Students must learn English as one of international languages is the most widely used language in the world (Abrar et al., 2018; Marzulina, Pitaloka, \& Yolanda, 2019; Mukminin et al., 2019). In Indonesia, English as foreign language is learned by students of Elementary school, Junior High School, Senior High School and Vocational School , until University level (Marzulina, Mukminin, et al., 2019,). While Erlina argues that English as one of the compulsory subject that is need to be learnt either for its receptive or productive skill (Erlina et al., 2019). Students have to master English orally and written form to pass their English examination(Astrid et al., 2019).

The second research was done by Darmayenti and Nofel Nofiadri to the first-year students of State Institute of Islamic Studies Imam Bonjol Padang, academic year 2012/2013. According to Darmayenti and Nofiadri, Mingle Model is a unique strategy in increasing students' speaking ability because it can make the students' accuracy and fluency becomes much better (Darmayenti \& Nofiadri, 2015). Mingle Model provides real world communication, a meaningful conversation which promotes their motivation in speaking. One kind of activities which can be used while Mingle Model was implemented is role play. According to Harmer and Nation, role play is one of activities that can be proposed in evaluating students' speaking skill (Jeremy Harmer, 2007; Nation, 2008).

One of the characteristics of Mingle Model is students have to talk with their pair, or in small groups. Students who are usually reluctant to talk in big group will be more relaxed to discussed with their pair or in small group (Brown, 2003; Frazier \& Brown, 2001). In addition, Harmer and Hedge also stated that Mingle Model could create a cozy learning atmosphere, lowering the affective filter, and providing effective motivation strategy from students (J. Harmer, 2004; Jeremy Harmer, 2007; Hedge, 2003). The teaching and learning English in Indonesia has been designed to help students to use English both in written and spoken forms(Gan, 2013; Indrawati, 2017; Marriam Bashir; Muhammad Azeem; Ashiq Hussain Dogar, 2016; Richards, 2010; "THE IMPORTANCE OF TEACHING LISTENING AND SPEAKING SKILLS," 2018). Students have to master English competence and know how to perform it in daily life in order to be well communicated in this foreign language (Indrawati, 2018; Pakula, 2019).

\section{Conclusion}

The author should clearly explain the important conclusions of the research highlighting its significance and relevance. 


\subsection{Conclusions of the Study}

This shows you everything simpler about the result of research finding elaborated in the previous chapter. In experimental group, every student had chance to talk at class and got the information while completing list of questions in the cards from some students. After that some of them did presentation in front of class. The implementation of Mingle Model in the first grade of Vocational High School Number 1 Simpangkatis, Bamgka was accepted and done well by almost all students' of TKI 2 class. It was proven by the observation sheet analysis. The attendance was very good category. They did pay attention for the materials and instructions. Then, they were active enough in the class. At last, they did the almost all of activities well. In experimental group, their attendance all was very good in every meetings, their attention was one meeting average, two meetings good and seven meetings very good, the activeness during meetings was nine meetings good and one meeting average, and doing activities were two meetings good and other very good category. All points were mostly 'good' and 'very good' categories during the meetings based on above explanations..

Based on the statistical analysis of the evidence in the previous chapter, the researcher concludes that there was a significant difference in students' speaking skill, between students who were taught by using Mingle Model and those students who were taught by Non-Mingle Model. The students who were taught by using Mingle Model in experimental group got higher score than the students who were taught by Non-Mingle Model in control group. Based on the result of statistical analysis, it showed t-obtained score 3.56. Then, the critical value of $t$-table was 2.00. That score was clearly higher than critical value of $t$-table. Therefore, the alternative hypothesis (Ha) was accepted and null hypothesis was rejected. It means that there was a significant difference in speaking skill between students who were taught by using Mingle Model and students who were taught by using Non-Mingle Model. Based on the evidence above, the writers states the Mingle Model was effective to improve students' speaking skill of the tenth grade of Vocational High School Number 1 Simpangkatis.

\subsection{Suggestions of the Study}

The suggestion related to the conclusions above is that Mingle Model is recommended to be applied by the teacher in the class for improving students' speaking skill. This model gives every student a possible chance to practice their speaking every meeting and creates comfortable atmosphere for the students during the learning process.

\section{References}

0. Creswell, J. W. (2012). Educational research: Planning, conducting, and evaluating quantitative and qualitative research. Educational Research.

Abrar, M., Mukminin, A., Habibi, A., Asyrafi, F., Makmur, M., \& Marzulina, L. (2018). "If our English isn't a language, what is it?" Indonesian EFL Student Teachers' Challenges Speaking English. Qualitative Report.

Astrid, A., Marzulina, L., Erlina, D., Harto, K., Habibi, A., \& Mukminin, A. (2019). Teaching writing to efl student teachers: Teachers' intervention and no teachers' intervention through peer feedback writing techniques. Universal Journal of Educational Research. https://doi.org/10.13189/ujer.2019.070908

Borzova, E. (2014). Mingles in the Foreign Language Classroom. English Teaching Forum.

Brown, H. D. (2003). Language Assesment Principles and Classroom Practice. Pearson Longman.

Darmayenti, D., \& Nofiadri, N. (2015). Mingle Model for Teaching English Speaking Skill for College Students. AlTa Lim Journal. https://doi.org/10.15548/jt.v22i1.115

Dewi, R. S., Kultsum, U., \& Armadi, A. (2016). Using Communicative Games in Improving Students' Speaking Skills. English Language Teaching. https://doi.org/10.5539/elt.v10n1p63

Erlina, D., Marzulina, L., Astrid, A., Desvitasari, D., Sapriati, R. S., Amrina, R. D., ... Habibi, A. (2019). Linguistic intelligence of undergraduate EFL learners in higher education: A case study. Universal Journal of Educational Research. https://doi.org/10.13189/ujer.2019.071012 
Fraenkel, J. R., \& Wallen, N. E. (2009). Methodology glossary. How to Design and Evaluate Research in Education. Frazier, S., \& Brown, H. D. (2001). Teaching by Principles: An Interactive Approach to Language Pedagogy. TESOL Quarterly. https://doi.org/10.2307/3587655

Gan, Z. (2013). Learning to teach english language in the practicum: What challenges do non-native ESL student teachers face? Australian Journal of Teacher Education. https://doi.org/10.14221/ajte.2013v38n3.3

Ganna. (2018). Teachers' Strategies in Teaching Speaking (a Case Study of an English Teacher in Sma Negeri 1 Toraja Utara). Teachers' Strategies in Teaching Speaking.

Gunn, C. L. (2003). Exploring second language communicative competence. Language Teaching Research. https://doi.org/10.1191/1362168803lr124oa

Harmer, J. (2004). Review: Methodology in Language Teaching: an Anthology of Current Practice. ELT Journal. https://doi.org/10.1093/elt/58.1.80

Harmer, Jeremy. (2007). How to Teach English 2nd Edition. Education. https://doi.org/10356/15300

Hedge, T. (2003). The Practice of English Language Teaching. ELT Journal. https://doi.org/10.1093/elt/57.4.401

Indrawati, I. (2017). My Insights on Learning Modern English Grammar. Tarbawy: Jurnal Pendidikan Islam. https://doi.org/10.32923/tarbawy.v4i1.812

Indrawati, I. (2018). Improving Tadris Bahasa Inggris Students' Competency of Curriculum Development in Language Education through Investigating SMU Teachers' Perceptions on the Implementation of 2013 Curriculum. Tarbawy: Jurnal Pendidikan Islam. https://doi.org/10.32923/tarbawy.v5i2.837

Indrawati, I., \& Widiana, A. (2019). Improving Students' Reading Comprehension in Narrative Text through Thieves Strategy to the 10th Grade Students of MAN 1 Pangkalpinang. Scientia: Jurnal Hasil Penelitian. https://doi.org/10.32923/sci.v4i2.1016

Kothari, C. (2004). Research methodology: methods and techniques. New Age International. https://doi.org/http://196.29.172.66:8080/jspui/bitstream/123456789/2574/1/Research\%20Method ology.pdf

Marczyk, G., DeMatteo, D., \& Festinger, D. (2005). Essentials of research design and methodology essentials of behavioral science. Book.

Marriam Bashir; Muhammad Azeem; Ashiq Hussain Dogar. (2016). Factor Effecting Students ' English Speaking Skills. British Journal of Arts and Social Sciences.

Marzulina, L., Mukminin, A., Erlina, D., Astrid, A., Ajriyah, N., Holandiyah, M., \& Habibi, A. (2019). The grammatical awareness of student teachers: The case of an english education study program in Indonesia. Universal Journal of Educational Research. https://doi.org/10.13189/ujer.2019.070902

Marzulina, L., Pitaloka, N. L., \& Yolanda, A. D. (2019). Learning Styles and English Proficiency of Undergraduate EFL Students at One State Islamic University in Sumatera, Indonesia. Edukasi: Jurnal Pendidikan Dan Pengajaran. https://doi.org/10.19109/ejpp.v6i1.3203

Mukminin, A., Masbirorotni, Marzulina, L., Erlina, D., Habibi, A., Fridiyanto, ... Nurulanningsih. (2019). Documenting undocumented motives influencing the career choice of the first-year science and math student teachers in Indonesia. Library Philosophy and Practice.

Nation, I. S. P. (2008). Teaching Vocabulary: Strategies and Techniques. Teaching Vocabulary: Strategies and Techniques.

Pakula, H.-M. (2019). Teaching speaking. Apples - Journal of Applied Language Studies. https://doi.org/10.17011/apples/urn.201903011691

Rasinger, S. M. (2013). Quantitative research in linguistics. An introduction. Research methods in linguistics.

Richards, J. C. (2001). Curriculum Development in Language Teaching. Curriculum Development in Language Teaching. https://doi.org/10.1017/cbo9780511667220

Richards, J. C. (2010). Competence and performance in language teaching. RELC Journal. https://doi.org/10.1177/0033688210372953

Syaiful, S., Mukminin, A., Habibi, A., Marzulina, L., Astrid, A., \& Tersta, F. W. (2019). Learning in the digital era: Science education students' perception on the snss use in the context of english for specific course. 
Scientia: Jurnal Hasil Penelitian Vol. 5, Nomor 2, Desember 2020

EISSN: 2655-3716

https://jurnal.lp2msasbabel.ac.id/index.php/sci

Elementary Education Online. https://doi.org/10.17051/ilkonline.2019.610143

THE IMPORTANCE OF TEACHING LISTENING AND SPEAKING SKILLS. (2018). World Science. https://doi.org/10.31435/rsglobal_ws/12062018/5881

Wallen, N. E., \& Fraenkel, J. R. (2001). Educational research: A guide to the process, 2nd ed.Educational research: A guide to the process, 2 nd ed. 